\title{
Identifikasi Profil Literasi Sains Mahasiswa PGSD
}

\author{
Kintan Limiansih, Maria Melani Ika Susanti \\ Universitas Sanata Dharma \\ kintan@usd.ac.id
}

\section{Article History}

received 22/10/2021

revised 12/11/2021

accepted 24/12/2021

\begin{abstract}
Scientific literacy is a competency to understand the environment and the problems faced by society. This study aims to measure the scientific literacy of students from Papua in PGSD USD. This type of research is quantitative descriptive with survey method. The population in this study were 72 students of the second semester of PGSD collaboration with the Regional Government (Pemda) of Papua. The sampling technique was a voluntary sampling design with 66 respondents involved. The instrument to be used is in the form of scientific literacy test questions which were developed based on the main scientific literacy competencies recommended by PISA 2018 and have been validated with a score of 3.68 (very good category). The average scientific literacy score of the entire sample was 51.93 (low category). The highest scientific literacy competence with a total score of 141.87 (max.198) is explaining phenomena scientifically. Meanwhile, the lowest competency with a total score of 94.9 ( $\max 198)$ is the ability to interpret data and facts scientifically.
\end{abstract}

Keywords: scientific literacy, students, Papua

\begin{abstract}
Abstrak
Literasi sains merupakan kompetensi untuk memahami lingkungan hidup dan masalah yang dihadapi oleh masyarakat. Penelitian ini bertujuan untuk mengukur literasi sains mahasiswa dari Papua di Pendidikan Guru Sekolah Dasar Universitas Sanata Dharma (PGSD USD). Jenis penelitian ini adalah deksriptif kuantitatif dengan metode survey. Populasi dalam penelitian ini adalah mahasiswa semester II PGSD jalur kerjasama Pemerintah Daerah (Pemda) Papua sebanyak 72 mahasiswa. Teknik pengambilan sampel adalah voluntary sampling design dengan 66 responden terlibat. Instrumen yang digunakan berupa soal tes literasi sains yang dikembangkan berdasarkan kompetensi utama literasi sains yang direkomendasikan PISA 2018 dan telah divalidasi dengan skor 3,68 (kategori sangat baik). Rata-rata skor literasi sains seluruh sampel adalah 51,93 (kategori rendah). Kompetensi literasi sains tertinggi dengan jumlah skor 141,87 (maks.198) adalah menjelaskan fenomena secara ilmiah. Sedangkan kompetensi yang terendah dengan jumlah skor 94,9 (maks 198) adalah kemampuan menginterpretasi data dan fakta secara ilmiah.
\end{abstract}

Kata kunci: literasi sains, mahasiswa, Papua 


\section{PENDAHULUAN}

Kompetensi utama sumber daya manusia pada abad-21 yaitu literasi, berpikir inventif, komunikasi yang efektif, dan produktivitas yang tinggi (Bagasta, 2018). World Economic Forum tahun 2016 juga menyatakan bahwa peserta didik memerlukan 16 keterampilan agar mampu bertahan di abad 21, yakni fondasi literasi atau literasi dasar, kompetensi, dan karakter (Wiedarti et al., 2016). Literasi sains menjadi salah satu dari 16 keterampilan yang dimaksud. Literasi sains merupakan kemampuan untuk menggunakan pengetahuan dan prinsip ilmiah untuk memahami lingkungan dan menguji hipotesis. Literasi sains berfungsi untuk memahami lingkungan hidup, kesehatan, ekonomi, dan masalah lain yang dihadapi oleh masyarakat modern yang bergantung pada teknologi dan perkembangan ilmu pengetahuan (Widya \& Sanjaya, 2017). Pengembangan literasi sains berperan untuk memperbaiki pengambilan keputusan, di tingkat lingkungan sosial maupun pribadi. Oleh sebab itu, penguasaan literasi sains oleh masyarakat menjadi penting untuk bertahan hidup di dunia yang semakin modern dan dinamis (Ilsadiati, Mislinawati, 2017).

Literasi sains menurut PISA diartikan sebagai "the capacity to use scientific knowledge, to identify questions and to draw evidence-based conclusions in order to understand and help make decisions about the natural world and the changes made to it through human activity" (Budiarti, 2021). Dari definisi tersebut, literasi sains dimaknai sebagai kemampuan seseorang menggunakan pengetahuan sains maupun keterampilan proses ilmiah untuk memahami dan membuat keputusan tentang lingkungan alam. Literasi sains merupakan kemampuan ilmiah individu untuk menggunakan pengetahuan yang dimilikinya pada proses identifikasi masalah, memperoleh pengetahuan baru, menjelaskan fenomena ilmiah, dan menarik kesimpulan berdasarkan bukti yang berhubungan dengan isu ilmiah (Wulandari \& Wulandari, 2016). Indikator literasi sains antara lain mengidentifikasi pendapat ilmiah yang valid, melakukan penelusuran literatur yang efektif, memahami elemen-elemen desain penelitian dan bagaimana dampaknya terhadap temuan/kesimpulan, membuat grafik secara tepat dari data, memecahkan masalah menggunakan keterampilan kuantitatif, termasuk statistik dasar, memahami dan menginterpretasikan statistik dasar, dan melakukan inferensi, prediksi, dan penarikan kesimpulan berdasarkan data kuantitatif (Rahmadani et al., 2018).

Literasi sains dapat bermanfaat bagi individu dan juga masyarakat umum. Individu yang memiliki keterampilan literasi sains memiliki kemampuan menyelesaikan masalah dengan menggunakan konsep-konsep sains yang dimiliki (Rahmadani et al., 2018; Bagasta, 2018). Bagi masyarakat, literasi sains erat hubungannya dengan perkembangan perekonomian suatu negara. Masyarakat yang objektif, berproses, dan memiliki kemampuan sains yang mumpuni akan mencetak tenaga ahli yang handal, ilmuwan, insinyur, dan professor yang mampu meningkatkan perekonomian negaranya (Windyariani, 2018).

Faktanya, kemampuan literasi sains siswa di Indonesia masih rendah. Hasil studi PISA 2015, literasi sains sebesar 403 poin terletak pada peringkat 62 dari 70 negara, bahkan skor masih di bawah negara tetangga Thailand, Vietnam, dan Singapura yaitu berturutturut 421, 525, dan 556 (Bagasta, 2018). Adapun perkembangan hasil PISA tahun 2018 khususnya pada literasi sains, Indonesia menempati posisi 70 dari 78 negara (Schleicher, 2019). Hasil tersebut menunjukkan bahwa skor rata-rata literasi sains Indonesia berada di bawah rata-rata skor internasional. PISA menetapkan tiga aspek dari komponen kompetensi/proses sains yang diukur dalam literasi sains. Ketiga kompetensi tersebut yaitu mengidentifikasi isu-isu (masalah) ilmiah, menjelaskan fenomena, dan menggunakan bukti ilmiah sesuai perkembangan teknologi (Winata, 2018). Ketiga kompetensi ini menjadi tantangan yang perlu diselesaikan oleh sekolah- 
sekolah di Indonesia.

Tantangan berbagai jenjang pendidikan, dari tingkat SD hingga perguruan tinggi, untuk mengembangkan literasi sains siswa. Berdasarkan penelitian sebelumnya, siswa SMASMP diindikasikan memiliki kemampuan literasi sains yang rendah (Fadlika et al., 2020; Rahmadani et al., 2018; Hidayah et al., 2019). Siswa belum mampu secara optimal mengidentifikasi pendapat ilmiah, menelusuri literatur, memahami elemen desain penelitian, membuat grafik sebesar, memecahkan masalah, memahami dan menginterpretasikan statistik dasar, serta menarik kesimpulan sebesar (Fadlika et al., 2020). Selain itu, kemampuan siswa dalam menjelaskan fenomena saintifik, mengevaluasi dan mendesain investigasi saintifik, melakukan interpretasi data dan eksperimen juga belum optimal (Hidayah et al., 2019). Di jenjang sekolah dasar, $70 \%$ siswa siswa kelas $\mathrm{V}$ di salah satu SD memiliki kemampuan literasi sains yang rendah (Winata, 2018). Permasalahan di jenjang sekolah dasar serupa dengan permasalahan di SMP dan SMA. Siswa belum mampu secara optimal membuat grafik berdasarkan data dan memecahkan masalah menggunakan keterampilan kuantitatif termasuk statistik dasar. Jika ditinjau secara global pada aspek konten, proses, dan konteks sains, pencapaian literasi sains siswa adalah sebagai berikut: $45 \%$ untuk aspek konten, $52 \%$ untuk aspek proses, dan 48\% untuk aspek konteks sains (Widiyati et al., 2020).

Literasi sains perlu dikembangkan sejak dini, pada jenjang sekolah dasar sehingga secara simultan siswa memiliki kompetensi yang semakin lengkap. Literasi sains potensial dikembangkan di tingkat SD dengan adanya muatan pembelajaran IPA yang dilengkapi dengan kompetensi dasar ranah pengetahuan dan keterampilan. Pembelajaran IPA yang optimal terjadi jika siswa diarahkan untuk mencari tahu melalui serangkaian proses penemuan sehingga membantu mereka memperoleh pemahaman yang lebih mendalam (Listiani, 2016). Serangkaian proses penemuan yang identik dalam pembelajaran IPA dapat saling beririsan dengan konsep literasi. Secara paralel siswa mengalami perkembangan keterampilan untuk membaca, menulis, menggunakan bahasa lisan yang akuntabel, serta terlibat dalam proses penalaran yang ilmiah.

Keberhasilan literasi sains siswa dalam pembelajaran ditentukan oleh faktor internal dan eksternal siswa. Faktor yang menyebabkan kemampuan literasi sains siswa yaitu ketertarikan pada sains, motivasi belajar, strategi guru dalam pembelajaran, dan fasilitas sekolah (Hidayah et al., 2019). Salah satu pihak yang dapat membantu siswa memiliki literasi sains yang baik adalah guru. Strategi pembelajaran, konten pembelajaran, fasilitas belajar, media pembelajaran, dan aktivitas pembelajaran yang kondusif dapat dirancang oleh guru untuk mengoptimalkan berkembangnya literasi sains siswa.

Perguruan tinggi dengan program pendidikan calon guru dapat berperan membantu mahasiswa untuk memiliki literasi sains yang baik. Harapannya ketika menjadi guru kelak, mereka dapat menentukan strategi pembelajaran yang mengoptimalkan kemampuan literasi sains siswanya. Program Studi (Prodi) PGSD, Universitas Sanata Dharma pada tahun 2019 dan 2020 menerima mahasiswa kerja sama dari Papua sebanyak 27 mahasiswa (semester 4) dan 72 mahasiswa (semester 2). Prodi PGSD diharapkan mampu mendampingi mahasiswa Papua sampai dengan paripurna menyelesaikan studi di USD. Kabupaten Mappi menjadi salah satu daerah yang mengirimkan putra daerahnya ke USD. Berdasarkan skor tes masuk mahasiswa Mappi (skala skor 0 - 100), kemampuan calistung mahasiswa masih rendah. Fakta ini menunjukkan perlu adanya perhatian khusus, termasuk pemetaan kemampuan mahasiswa di bidang sains untuk memutuskan bentuk pendampingan sebagai upaya tindak lanjut yang sesuai dalam proses perkuliahaan IPA. 
Di sisi lain, penelitian tentang kemampuan literasi sains mahasiswa Papua telah dilakukan di salah satu perguruan tinggi di Papua. Sebanyak 138 orang mahasiswa telah diteliti dan $53 \%$ memberikan jawaban soal dengan menuliskan kambali wacana pada soal atau bahkan kosong (Hendri \& Hasriani, 2019). Artinya, mahasiswa tidak memiliki konsep yang jelas dalam menjelaskan sebuah fenomena. Sedangkan rerata nilai literasi sains mahasiswa semester 2-6 hanya sebesar 2,5 dengan kualifikasi sangat kurang (Hendri \& Hasriani, 2019). Temuan yang juga menarik dalam penelitian ini adalah terdapat perbedaan nilai rerata literasi sains mahasiswa yang berasal dari orang asli Papua (OAP) dan bukan orang asli Papua.

Berdasarkan atas pentingnya literasi sains untuk dikembangkan sejak sekolah dasar, peran guru dalam mengoptimalkannya, serta kekhususan karakteristik mahasiswa PGSD dari Papua maka peneliti tertarik untuk mengidentifikasi literasi sains mahasiswa dari Papua. Hasil penelitian ini diharapkan dapat menjadi dasar pengelolaan dalam mendesain pembelajaran IPA pada semester berikutnya.

\section{METODE}

Penelitian ini menggunakan metode deskriptif kuantitatif dengan metode survey (Sugiyono, 2014). Populasi dalam penelitian ini adalah seluruh mahasiswa PGSD semester 2, jalur kerja sama Pemerintah Daerah (Pemda) Papua sebanyak 72 mahasiswa. Sampel dalam penelitian ini diambil dengan teknik voluntary sampling. Responden memiliki kebebasan untuk terlibat atau tidak dalam penelitian ini (Murairwa, 2015). Instrumen penelitian berupa soal tes literasi sains yang dikembangkan berdasarkan indikator literasi sains menurut PISA (Schleicher, 2019). Instrumen soal berdasarkan validasi ahli memiliki kualitas yang sangat baik (skor 3,68) dan layak digunakan setelah dilakukan revisi.

Data profil literasi sains mahasiswa berupa skor dengan rentang 0-3 untuk setiap item soal. Selanjutnya analisis dilakukan sebagai berikut:

a. Identifikasi skor literasi sains seluruh mahasiswa untuk setiap indikator

Skor ini diperoleh dengan menjumlahkan seluruh skor mahasiswa (66 responden) untuk setiap item soal (14 soal). Khusus untuk skor pada item soal nomor 10-11, besarnya dirata-rata karena 2 soal ini mewakili 1 indikator.

$$
\text { Skor setiap indikator }=\sum \text { skor seluruh responden }
$$

b. Identifikasi skor literasi sains seluruh mahasiswa untuk setiap kompetensi

Setelah mendapatkan skor masing-masing indikator, berikutnya adalah menghitung rata-rata skor untuk setiap kompetensi literasi sains.

$$
\text { Rata }- \text { rata skor tiap kompetensi } L S=\frac{\sum \text { skor indikator tiap kompetensi }}{\Gamma \text { indikator }}
$$

c. Perhitungan ketercapaian literasi sains seluruh responden

Persentase ketercapaian literasi sains (LS) ini diperoleh dari menghitung skor literasi sains tiap responden kemudian menghitung rata-ratanya untuk seluruh responden menggunakan rumus:

$$
\begin{gathered}
\text { Skor LS tiap responden }=\frac{\text { Skor responden menjawab benar }}{\text { Skor maksimum }(42 \text { skor })} \times 100 \% \\
\text { Rata }- \text { rata }=\frac{\sum \text { skor LS tiap responden }}{\text { Jumlah responden }} \times 100 \%
\end{gathered}
$$


Rata-rata yang diperoleh akan diklasifikasikan berdasarkan kategori yang dapat dilihat pada tabel 1 berikut (Fadlika et al., 2020).

Tabel 1: Kategori Capaian Literasi Sains

\begin{tabular}{ccc}
\hline No & Kategori & Persentase (\%) \\
\hline 1 & Tinggi & $>75$ \\
\hline 2 & Sedang & $60-75$ \\
\hline 3 & Rendah & $<60$ \\
\hline
\end{tabular}

\section{HASIL DAN PEMBAHASAN}

Identifikasi profil literasi sains mahasiswa kerjasama dilakukan dengan memberikan tes pada tanggal 7 April 2021 selama 3 jam dengan sistem mahasiswa menerima soal dalam bentuk hardcopy kemudian peneliti memandu melalui Zoom Meeting. Selain itu, dilakukan dialog untuk mengonfirmasi jawaban mahasiswa pada 14 April 2021. Responden yang menjadi sampel dalam penelitian ini adalah 66 mahasiswa yang secara sukarela terlibat. Responden telah mempelajari materi yang dimuat dalam konten soal. Jawaban responden kemudian dianalisis menggunakan rubrik penilaian dengan setiap soal memiliki skor maksimal 3.

a. Identifikasi skor literasi sains seluruh mahasiswa untuk setiap indikator
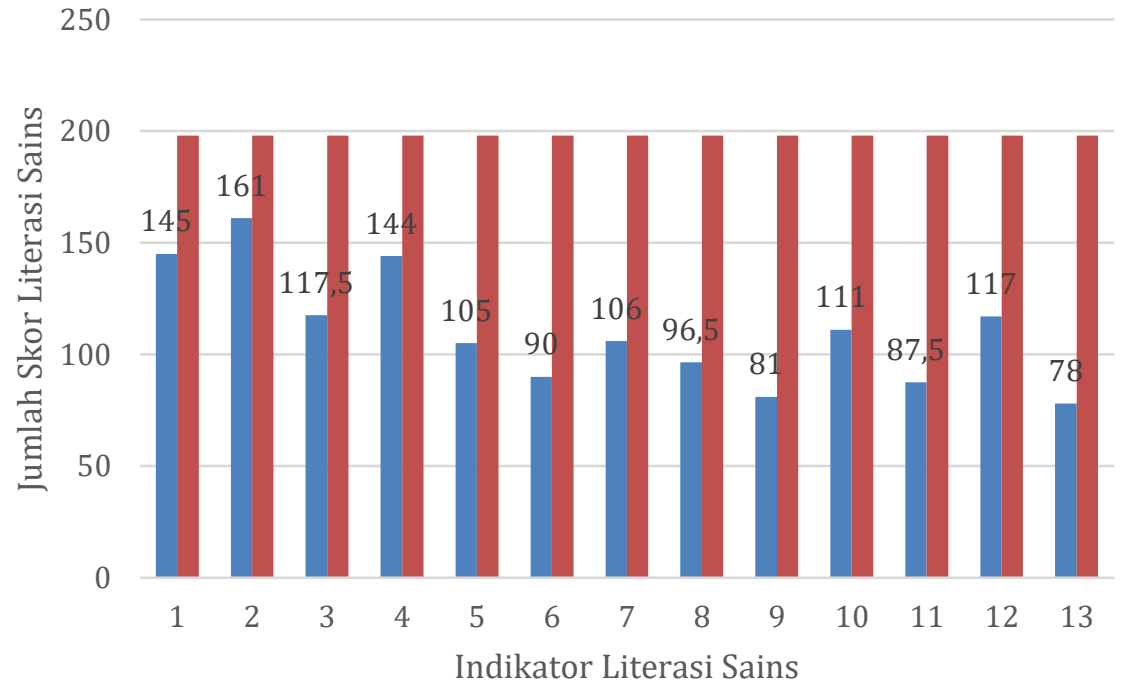

- Jumlah skor

- Skor maksimal

\section{Gambar 1. Grafik skor tes setiap indikator}

Indikator 1-13 yang dimaksud pada grafik di atas dijawarkan dalam tabel di bawah ini.

Tabel 2: Indikator Literasi Sains

\begin{tabular}{|c|c|c|}
\hline $\begin{array}{l}\text { Kompetensi } \\
\text { IImiah dalam } \\
\text { Literasi } \\
\text { Sains } \\
\end{array}$ & Indikator & Nomor \\
\hline $\begin{array}{l}\text { Mengidentifik } \\
\text { asi } \quad \text { isu-isu }\end{array}$ & $\begin{array}{l}\text { Mengidentifikasi, menggunakan dan merumuskan atau, } \\
\text { membuat sebuah penjelasan untuk suatu fenomena }\end{array}$ & 1 \\
\hline (masalah) & Membuat prediksi pada suatu kejadian & 2 \\
\hline ilmiah & Memberikan penjelasan/alasan suatu hipotesis & 3 \\
\hline & Menjelaskan penerapan ilmu pengetahuan dala kehidupan & 4 \\
\hline
\end{tabular}




\begin{tabular}{|c|c|c|}
\hline $\begin{array}{l}\text { Kompetensi } \\
\text { Ilmiah dalam } \\
\text { Literasi } \\
\text { Sains }\end{array}$ & Indikator & Nomor \\
\hline \multirow{4}{*}{$\begin{array}{l}\text { Menjelaskan } \\
\text { fenomena } \\
\text { ilmiah }\end{array}$} & Menentukan pertanyaan hipotetik & 5 \\
\hline & $\begin{array}{l}\text { Mengusulkan suatu cara ilmiah untuk menjawab suatu } \\
\text { pertanyaan }\end{array}$ & 6 \\
\hline & $\begin{array}{l}\text { Mengevaluasi suatu cara ilmiah untuk menjawab suatu } \\
\text { pertanyaan }\end{array}$ & 7 \\
\hline & $\begin{array}{l}\text { Menjelaskan dan mengevaluasi berbagai cara yang } \\
\text { digunakan ilmuwan untuk memastikan keandalan data dan } \\
\text { objektivitas serta generalisasi penjelasan }\end{array}$ & 8 \\
\hline \multirow{5}{*}{$\begin{array}{l}\text { Menggunaka } \\
\text { n bukti ilmiah }\end{array}$} & Mentransfer data dari satu bentuk ke bentuk lainnya & 9 \\
\hline & $\begin{array}{l}\text { Menganalisis dan menginterpretasi data untuk kemudian } \\
\text { membuat kesimpulan }\end{array}$ & 10 \\
\hline & Mengidentifikasi asumsi, fakta, dan penjelasan ilmiah & 11 \\
\hline & $\begin{array}{l}\text { Membedakan argumen yang berdasarkan fakta ilmiah dan } \\
\text { teori atau berdasarkan umum }\end{array}$ & 12 \\
\hline & $\begin{array}{l}\text { Mengevaluasi pendapat ilmiah dari sumber yang berbeda } \\
\text { (koran, jurnal, internet) }\end{array}$ & 13 \\
\hline
\end{tabular}

Berdasarkan diagram tersebut, dapat diinterpretasikan bahwa skor tertinggi ada pada indikator 2, yaitu "membuat prediksi pada suatu kejadian", sedangkan indikator dengan skor terendah adalah indikator 13 yaitu "Mengevaluasi pendapat ilmiah dari sumber yang berbeda (koran, jurnal, internet)". Apabila dikaji lebih mendalam berdasarkan argumen mahasiswa baik secara tertulis maupun lisan, berikut dipaparkan temuan kemampuan literasi sains setiap indikator.

1. Indikator 1: Mengidentifikasi, menggunakan dan merumuskan atau, membuat sebuah penjelasan untuk suatu fenomena

Kemampuan ini dilihat dengan soal tes berupa cerita bergambar. Mahasiswa perlu menyebutkan beberapa alat ukur (termometer, penggaris, timbangan massa, stopwatch) dan besaran yang diukur (volume, suhu, massa, waktu) yang tersirat dalam cerita tersebut. Sebagian besar mahasiswa mampu mengidentifikasi 1 alat ukur dan satuan yang diukur yaitu termometer untuk mengukur suhu. Terdapat 8 mahasiswa yang menjawab lengkap, lebih dari 1 alat ukur dan besarannya. Terdapat pula mahasiswa yang menuliskan alat yang bukan kategori alat ukur, misalnya panci dan kompor gas (2 mahasiswa). Ada sebagian kecil jawaban yang tidak sesuai konteks soal, bahkan mahasiswa tidak menjawab. Terkait dengan kemampuan menjelaskan suatu fenomena, sebagian besar mahasiswa belum memberikan penjelasan yang ilmiah. Contohnya pada pertanyaan "mengapa skala pada alat ukur termometer dapat naik ketika digunakan untuk mengukur air panas?", sebagian besar responden menjawab "karena suhu air yang diukur panas". Jawaban tersebut megulang pertanyaan, belum mengarah pada penjelasan konseptual tentang pemuaian. Selain itu terdapat pula mahasiswa yang menjelaskan prosedur yang perlu dilakukan sehingga pengukuran akurat. Penjelasan ini tidak termasuk penjelasan ilmiah namun pengalaman prosedural. Meskipun demikian, terdapat 8 mahasiswa yang menjelaskan konsep pemuaian untuk kenaikan skala termometer.

2. Indikator 2: Membuat prediksi pada suatu kejadian

Kemampuan prediksi diukur dengan soal "..bagaimana hasil pengukuran yang akan diperoleh pada kegiatan tersebut”, harapannya mahasiswa dapat memprediksi salah satu hasil pengukuran, misalnya suhu. Suhu akan naik namun saat air mendidih suhu akan tetap. Sebagian mahasiswa memprediksi sesuai konsep 
perubahan wujud (44 mahasiswa). Sedangkan mahasiswa lain memprediksi bahwa suhu akan terus naik dan ada yang tidak menjawab. Hal ini menunjukkan mahasiswa dapat memprediksi suatu kejadian karena memiliki konsep awal yang benar.

3. Indikator 3: Memberikan penjelasan/alasan suatu hipotesis

Indikator ini dilihat dengan soal “..mengapa hasil pengukurannya demikian..?”, harapannya mahasiswa dapat menjelaskan penggunaan energi panas untuk merubah wujud sehingga suhu air mendidih relatif konstan. Jawaban mahasiswa sangat beragam, sebagian besar menjawab "karena alat ukur yang digunakan baik, termometer memiliki skala yang akurat". Ada pula yang menjawab konsep perpindahan panas pada kegiatan merebus air, perambatan panas secara konduksi, bahkan ada sebagian kecil tidak menjawab. Mahasiswa tampak kesulitan mengaitkan soal ini dengan jawaban sebelumnya. Sebagian besar mahasiswa mampu berhipotesis, namun ketika perlu menjelaskan hipotesisnya kesulitan. Penjelasan yang diberikan terkait fenomena umum yang ada dalam suatu kejadian, bukan berdasar hipotesis yang dibuat.

4. Indikator 4: Menjelaskan penerapan ilmu pengetahuan dala kehidupan seharihari

Kemampuan ini diukur dengan soal "contoh aktivitas/peristiwa sehari-hari yang menerapkan konsep seperti peristiwa di atas (perubahan suhu, pemuaian)". Sebagian besar mahasiswa dapat memberikan contoh yang sesuai, artinya mereka mampu memahami penerapan konsep ilmiah dalam kehidupan sehari-hari. Contoh yang disebutkan mahasiswa tidak banyak bervariasi, misalnya proses memasak nasi, memasak ubi, merebus air kopi, memasak mie, mendekatkan ember berisi air di dekat api, melelehkan lilin, atau melelehkan es krim dengan panas matahari. Ada pula yang menyebutkan dengan cotoh yang berbeda dari soal misalnya olahraga. Aktivitas yang disebutkan merupakan aktivitas sehari-hari yang mereka lakukan. Meskipun variasi jawaban kurang beragam, hal ini menunjukkan mahasiswa mampu memahami penerapan konsep perubahan suhu dan pemuaian pada kegiatan memasak.

5. Indikator 5: Menentukan pertanyaan yang dapat dijawab melalui percobaan

Mahasiswa diberi beberapa pertanyaan lalu memilih yang merupakan pertanyaan yang hipotetik, dapat dijawab melalui suatu percobaan. Secara lisan, mahasiswa diberi penjelasan karakteristik pertanyaan yang hipotetik (kebenarannya rendah) adalah adanya pengaruh suatu variabel dengan variabel lain. Karakteristik ini disampaikan supaya mahasiswa memiliki pemahaman sederhana yang jelas tentang pertanyaan hipotetik. Beberapa pertanyaan yang disediakan antara lain,

a. Apakah udara dapat memuai?

b. Mengapa benda dapat memuai?

c. Kapan benda mulai memuai ketika dipanaskan?

d. Berapa jumlah benda yang dapat memuai?

e. Apakah benda yang memuai akan kembali ke ukuran semula saat pemanasan dihentikan?

f. Bagaimana benda padat dapat memuai?

Pertanyaan hipotetik adalah poin a dan e. Mahasiswa telah dibantu dengan penggunaan kata tanya yang spesifik. Sebagian mahasiswa memilih pertanyaan yang sesuai namun sebagian lagi tidak. Jawaban yang mendominasi adalah a dan c. Poin c dipilih mahasiswa karena mereka dapat mudah mengidentifikasi apa yang akan dilakukan. Pertanyaan "kapan" identik dengan pengukuran waktu dan menggunakan stopwatch, berbekal asumsi ini mahasiswa memilih jawaban c. Meskipun demikian terdapat 33 mahasiswa yang menjawab pilihan a atau e (salah satu tepat) dan 4 mahasiswa yang menjawab pilihan a dan e. 
6. Indikator 6: Mengusulkan suatu cara ilmiah untuk menjawab suatu pertanyaan Kemampuan ini diukur dengan soal "percobaan apa yang dapat dilakukan untuk menjawab pertanyaan hipotetik yang dipilih...". Dalam menjawab soal ini, mahasiswa perlu merencanakan suatu percobaan dengan mendeskripsikan alat/bahan serta cara kerja. Skor pada indikator ini tergolong rendah, artinya mahasiswa belum dapat merencanakan kegiatan untuk menjawab pertanyaan. Sebagian kecil mahasiswa (23 responden) menuliskan alat dan bahan sederhana, tanpa ada jumlah atau karakteristik khusus. Rencana percobaan secara umum proses merebus air dan memanaskan lilin. Namun ada pula mahasiswa yang menjawab dengan ide spesifik yaitu pembuatan termometer dari selang. Selain itu mereka juga memaparkan prosedur sederhana yang tearah sesuai pertanyaan namun ada pula yang tidak lengkap sehingga belum dapat menjawab pertanyaan. Terdapat pula mahasiswa yang hanya menyebutkan beberapa alat atau hanya menyebutkan prosedurnya saja. Ada responden yang menyebutkan alat dan prosedur singkat namun tidak berkaitan dengan pemuaian, misalnya proses terbangnya tepung (mengalami perubahan volume namun bukan karena panas) atau kembali pada konsep pengukuran. Ada pula responden yang tidak menjawab.

7. Indikator $\mathbf{7}$ Mengevaluasi suatu cara ilmiah untuk menjawab suatu pertanyaan Mahasiswa perlu menentukan prosedur percobaan yang tepat untuk membuktikan pengaruh antar variabel. Terdapat 2 prosedur disandingkan dalam tabel kemudian mahasiswa memilih prosedur yang tidak tepat dan alasannya.

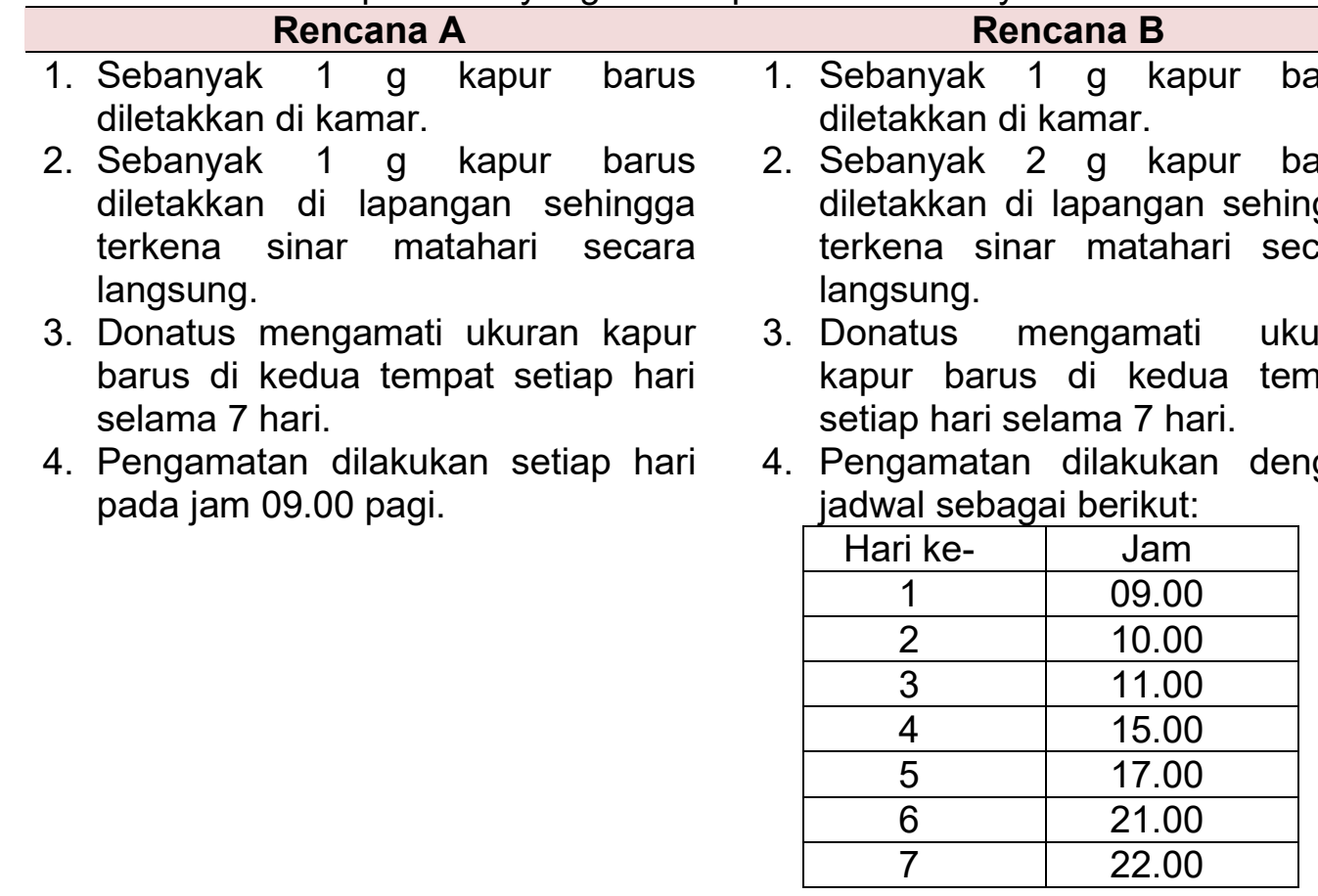

Prosedur B tidak tepat karena variabel massa dan waktu pengamatan tidak dikontrol. Sebagian besar mahasiswa mampu menentukan bahwa rencana B tidak tepat namun dengan alasan yang tidak logis.

Terdapat 10 mahasiswa yang menjawab tepat 2 variabel harus dikontrol, yaitu massa dan waktu pengamatan. Dari 10 mahasiswa tersebut, 2 mahasiswa memaparkan alasan detail yaitu perbedaan massa menyebabkan lama habisnya kapur barus akan berbeda serta waktu pengamatan yang dilakukan bervariasi akan mempengaruhi intensitas panas matahari. Sebagian mahasiswa menjawab dengan 1 variabel saja yaitu waktu dengan alasan waktu terlalu lama, waktu pengamatan sebaiknya lebih dari 7 hari, waktu malam hari tidak logis, dan sebagian besar 
menjawab tanpa alasan. Meskipun demikian terdapat temuan menarik yaitu 2 mahasiswa menyampaikan prosedur A tidak tepat karena tidak ada tabel sehingga jadwal tidak detail. Hal ini menunjukkan mahasiswa fokus pada bentuk prosedur, bukan pada isi prosedur.

8. Indikator 8: Menjelaskan dan mengevaluasi berbagai cara yang digunakan ilmuwan untuk memastikan keandalan data dan objektivitas serta generalisasi penjelasan

Kemampuan mengevaluasi keakuratan data dilakukan dengan pertanyaan evaluatif “..apakah alat ukur yang digunakan tepat dan rekomendasi alat lain”. Sebagian besar mahasiswa menjawab ada alat lain yang lebih akurat untuk mengukr yaitu jangka sorong. Meskipun demikian, 22 mahasiswa berpendapat tidak ada alat lain yang lebih akurat sehingga penggunaan penggaris atau mistar tepat dilakukan. Di sisi lain, terdapat 10 mahasiswa menyebutkan alat lain yang tidak sesuai fungsi misalnya kalorimeter, termometer, kaliper, neraca digital, dan kertas lakmus. Terdapat pula mahasiswa yang menyatakan alat ukur belum akurat namun tidak merekomendasikan perbaikan supaya lebih akurat.

9. Indikator 9: Mentransfer data dari satu bentuk ke bentuk lainnya

Kemampuan ini diukur dengan memilih grafik yang sesuai dengan tabel (transfer tabel menjadi grafik). Skor kemampuan ini masuk pada kategori 2 terendah, artinya sebagian besar mahasiswa belum dapat mentransfer data dari bentuk tabel ke bentuk grafik. Soal yang ada dikemas dalam bentuk pilihan ganda sehingga meminimalkan keterbatasan kemampuan mahasiswa untuk hal teknis (menggambar, menghitung).

10. Indikator 10: Menganalisis dan menginterpretasi data untuk kemudian membuat kesimpulan

Berdasarkan data yang ada, mahasiswa diminta menginterpretasi dengan bantuan pertanyaan "Yosep melakukan Gerak Lurus Beraturan pada menit ke berapa". Gerak lurus beraturan terjadi saat kecepatan tetap. Konsep ini menjadi dasar mahasiswa melakukan interpretasi. Faktanya, skor kemampuan interpretasi mahasiswa tidak maksimal. Sebagian besar mahasiswa dapat menyebutkan rentang waktu yang tepat saat kecepatan konstan, namun hanya 1 data. Seharusnya terdapat 4 rentang waktu. Hal ini menunjukkan sebagian besar mahasiswa memahami konsep gerak lurus namun tidak melihat pola yang berulang pada suatu data.

Kemampuan membuat kesimpulan ditinjau dengan mahasiswa diminta membuat kesimpulan umum berdasarkan data pada tabel. Terdapat 3 mahasiswa yang jawabannya tepat yaitu gerak lurus beraturan sekaligus gerak lurus berubah beraturan. Sebagian besar mahasiswa menjawab dengan 1 jawaban, gerak lurus dan ada pula yang menjawab GLB atau GLBB. Hal ini mengindikasikan mahasiswa belum memahami konsep perbedaan istilah GLB-GLBB. Mahasiswa juga menjawab dengan istilah baru, misalnya gerak verikal, gerak paralel, gerak translasi.

11. Indikator 11 Mengidentifikasi asumsi, fakta, dan penjelasan ilmiah dari suatu data

Kemampuan identifikasi fakta atau penjelasan ilmiah dari suatu data ditinjau dengan pertanyaan "Mengapa kalian menyimpulkan demikian?". Melalui pertanyaan ini harapannya mahasiswa dapat mengidentifikasi informasi yang ilmiah tentang gerak. Sebagian besar mahasiswa menjelaskan kesimpulan mereka tentang jenis gerak yang terjadi dengan alasan/asumsi yang umum, tidak berdasarkan tabel, misalnya karena jalannya lurus, tidak ada tikungan, tidak berbalik arah. Hal ini menunjukkan mahasiswa lebih kuat menggunakan asumsi mereka berdasarkan pengalaman dibandingkan melihat data pada tabel.

12. Indikator 12: Membedakan argumen yang berdasarkan fakta ilmiah dan teori atau berdasarkan asumsi umum 
Kemampuan ini ditinjau dengan mahasiswa memilih 2 dari sekian cara yang dapat dilakukan untuk menyelesaikan suatu permasalahan. Konteks masalah yang diambil adalah nelayan yang ingin mempercepat laju kendaraan. Terdapat 4 piliha cara yang sebagian tidak berdasarkan konsep ilmiah. Sebagian besar mahasiswa hanya dapat memilih 1 cara dan tanpa alasan. Hal ini menunjukkan mereka dapat mengidentifikasi solusi yang ilmiah dan tidak namun tidak mengetahui penjelasan koseptualnya. Meskipun demikian, terdapat 4 mahasiswa yang menjelaskan alasan dengan sangat baik, pengaruh satu variabel dengan yang lain dikaitkan dengan Hukum 2 Newton. Temuan menariknya sebagian mahasiswa memilih solusi yang tidak tepat, misalnya meletakkan ikan pada satu keranjang di belakang nelayan. Mahasiswa tidak menyadari bahwa meletakkan ikan dalam satu wadah tidak mengurangi massa yang kemudian mempengaruhi kecepatan.

13. Indikator 13: Mengevaluasi pendapat ilmiah dari sumber yang berbeda (koran, jurnal, internet)

Skor pada kemampuan ini adalah terendah dibandingkan dengan indikator lain. Artinya mahasiswa kesulitan untuk mengevaluasi pendapat ilmiah dari sumber yang berbeda. Kemampuan ini diukur dengan kegiatan mahasiswa perlu mencari informasi yang sesuai konsep Hukum 2 Newton yang berkaitan dengan kasus nelayan pengangkut ikan pada soal nomor 13. Faktanya hanya 9 mahasiswa memaparkan pendapat ilmiah disertai dengan sumbernya. Dari 9 mahasiswa ini, 6 di antaranya menyebutkan hanya 1 sumber. Sebagian besar mahasiswa menjelaskan pendapat pribadinya tentang konsep gerak. Terdapat temuan menarik, sebagian kecil mahasiswa menjawab dengan sumber yang jelas namun konsep tidak sesuai permasalahan, misalnya teori pengukuran. Terdapat pula mahasiswa yang hanya menyebutkan kata kunci teori yang tidak sesuai permasalahan dan tanpa penjelasan, bahkan ada yang menyebutkan nama tokoh. Fakta ini menunjukkan bahwa kemampuan mahasiswa mengakses informasi masih terbatas. Kemampuannya untuk mengenal kata kunci pencarian informasi yang sesuai juga belum optimal.

b. Identifikasi skor literasi sains seluruh mahasiswa untuk setiap kompetensi

Terdapat 3 kompetensi ilmiah yang diukur dalam literasi sains yang termuat pada soal-soal PISA (Schleicher, 2019), antara lain:

1. Menjelaskan fenomena secara ilmiah

2. Mengevaluasi dan merancang penyelidikan ilmiah

3. Menginterpretasi data dan fakta secara ilmiah

Kemampuan literasi sains mahasiswa berdasarkan tiap kompetensinya adalah:

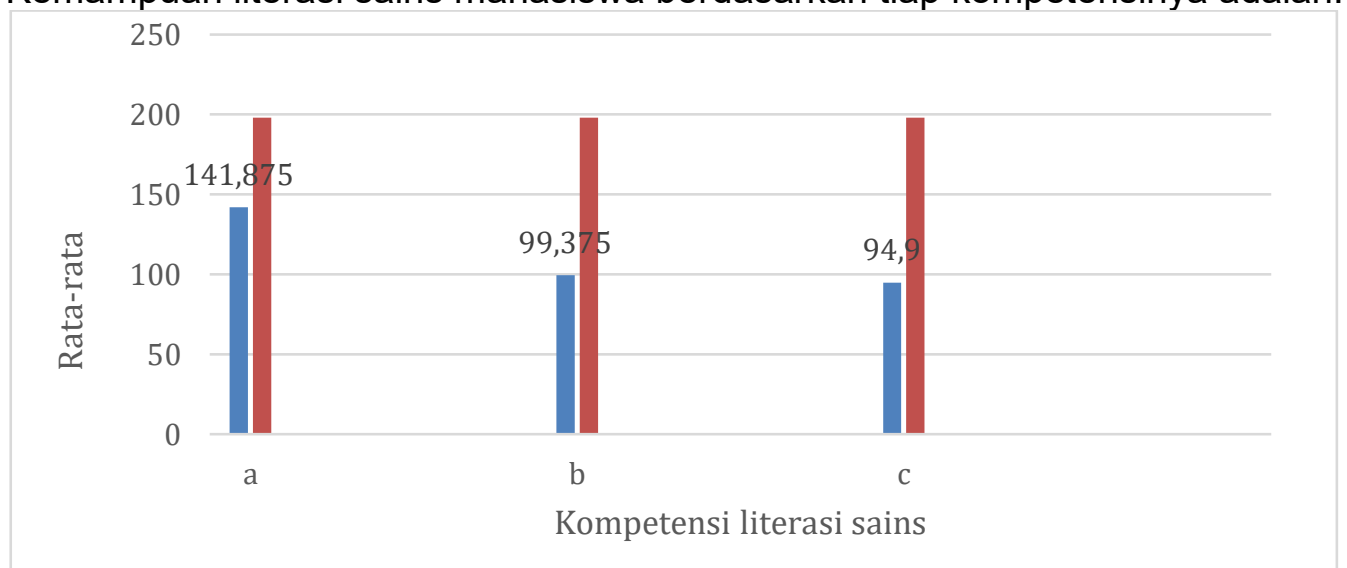

Gambar 2. Grafik Jumlah Skor Literasi Sains Seluruh Responden untuk Tiap Kompetensi 
Kemampuan tertinggi kompetensi a, artinya mahasiswa dapat mengenali permasalahan yang berkaitan dengan konsep ilmiah dan memberikan penjelasan meskipun dengan sederhana. Kemampuan literasi menurun berturut-turut untuk kompetensi b dan c. Mahasiswa belum mampu mengidentifikasi pertanyaan yang dapat diteliti dengan suatu percobaan, merancang suatu penyelidikan, bahkan mengevaluasi rencana penyelidikan. Kompetensi untuk menginterpretasi data dan fakta secara ilmiah juga masih rendah. Mahasiswa belum mampu untuk mentransfer data ke berbagai bentuk, menyimpulkan data dalam tabel, memilih sumber yang memuat konsep yang relevan dengan permasalahan.

c. Perhitungan rata-rata skor literasi sains seluruh responden

Berdasarkan analisis skor setiap responden, diperoleh fakta bahwa rata-rata persentase ketercapaian literasi sains keseluruhan adalah $51,93 \%$. Berdasarkan pengategorian literasi sains, persentase ini termasuk dalam kategori rendah (Fadlika et al., 2020).

Rendahnya kemampuan literasi sains mahasiswa disebabkan oleh beberapa faktor. Lingkungan dan iklim belajar di sekolah mempengaruhi pengalaman belajar mahasiswa. Apabila ditinjau dari pengalaman belajar responden yang berasal dari Kabupaten Mappi-Papua ini, mereka memiliki pengalaman belajar sains yang khusus. Berdasarkan penelitian terdahulu, diperoleh informasi bahwa tidak seluruh mahasiswa memiliki pengalaman belajar sains di tingkat sekolah dasar (Limiansih, 2021). Ini dapat menjadi alasan terbatasnya pengetahuan sains yang mahasiswa miliki sebagai bekal untuk menjelaskan fenomena yang terjadi di lingkungan sekitar secara ilmiah. Pembelajaran sains di SD bertujuan untuk mengenalkan peristiwa alam di kehidupan anak dan mengaitkannya dengan pengetahuan sains. Semakin ke atas jenjang pendidikan yang ditempuh maka semakin abstrak dan kompleks fenomena tersebut dijelaskan secara ilmiah. Berdasarkan data pada gambar 2, kemampuan responden dalam menjelaskan fenomena ilmiah belum mencapai skor maksimal. Hal ini menunjukkan adanya penguasaan konten yang belum optimal oleh mahasiswa.

Pengalaman belajar sains juga mempengaruhi kompetensi mahasiswa untuk melakukan penyelidikan dan mengolah data secara ilmiah. Dalam hal ini sains dipahami sebagai suatu pengetahuan sekaligus keterampilan. Pembelajaran sains yang dominan pada transfer informasi dari guru kepada siswa dapat menyebabkan minimnya olah keterampilan siswa. Berdasarkan penelitian terdahulu, pembelajaran sains yang dialami mahasiswa ketika mereka berada di tingkat SD adalah mencatat informasi dan penjelasan informasi dari guru (Limiansih, 2021). Minimnya pengalaman mahasiswa dalam melakukan penyelidikan dan mengolah data menyebabkan rendahnya kompetensi literasi sains ini.

Mahasiswa calon guru perlu dibantu untuk mengembangkan kemampuan literasi sains sehingga kelak dapat membantu siswanya memiliki literasi sains yang baik pula. Berdasarkan temuan rendahnya lietarsi sains mahasiswa, maka perlu dilakukan modifikasi kegiatan perkuliahaan yang dapat mengoptimalkan literasi sains mahasiswa. Beberapa modifikasi yang dapat dilakukan antara lain:

1. Membiasakan mahasiswa mengakses sumber informasi terpercaya. Berdasarkan data penelitian ini, indikator dengan skor terendah yaitu "mengevaluasi pendapat ilmiah dari sumber yang berbeda (koran, jurnal, internet, dIl)". Mahasiswa belum mahir mencari informasi dari beragam sumber yang ilmiah, bahkan mengevaluasi kredibilitas informasi dari sumber tersebut. Contoh sumber informasi yang disebut mahasiswa adalah nama surat kabar online (pikiranrakyat.com), blog, dan laman belajar online. Oleh sebab itu dalam perkuliahaan mahasiswa perlu diajak mengenal ciri sumber informasi yang 
terpercaya, memilih sumber, hingga mengevaluasi informasi yang sesuai dengan kebutuhannya.

2. Pembelajaran berbasis masalah sebagai usaha penguatan konten. Berdasarkan data penelitian ini, mahasiswa belum mampu secara optimal menjelaskan fenomena alam di sekitar secara ilmiah. Melalui studi kasus nyata, mahasiswa dapat dibantu menggali konsep ilmiah, mengklarifikasi kesalahan konsep, atau bahkan mengembangkan pemahaman konsep sains. Kasus nyata/data disajikan dalam bentuk grafik, gambar, diagram dan mahasiswa berlatih untuk memaknainya, menyimpulkan secara tepat, dan menafsirkan kecenderungan yang mungkin terjadi. Dengan demikian harapannya mahasiswa sekaligus mengalami perbaikan dalam kompetensi mengolah data ilmiah.

Penyelidikan ilmiah (inkuiri) mandiri oleh mahasiswa. Salah satu kompetensi literasi sains yang belum berkembang optimal adalah kemampuan untuk merencanakan dan melakukan penyelidikan. Iklim belajarn penjelasan materi dari guru meminimalisir pengalaman belajar dengan proses penyelidikan. Oleh sebab itu ketika ada suatu permasalahan atau pertanyaan, mahasiswa belum mampu menentukan cara untuk mencari jawabannya secara ilmiah. Perkuliahaan yang dilakukan perlu diisi dengan kegiatan eksperimen. Mahasiswa diberi kesempatan memahami tujuan dan menentukan perlengkapan eksperimen secara mandiri. Hal ini dapat diawali dengan memberikan lembar kerja terbuka. Mahasiswa dapat melengkap alat/bahan, prosedur, variable yang perlu dikontrol, diubah, diamati, serta dugaan data yang akan diperoleh.

\section{SIMPULAN}

Berdasar temuan didapatkan kesimpulan bahwa profil literasi sains mahasiswa PGSD dari Kabupaten Mappi, Papua telah teridentifikasi dengan capaian sebesar $51,93 \%$ dengan kategori rendah. Rendahnya kemampuan literasi sains mahasiswa disebabkan oleh beberapa faktor, di antaranya adalah lingkungan dan iklim belajar di sekolah yang dialami sebelumnya, sehingga mempengaruhi pengalaman belajar mahasiswa. Mengacu pada hasil temuan, Prodi PGSD merancang beberapa hal yang perlu dilakukan terhadap mahasiswa calon guru yang bersifat membantu pengembangan kemampuan literasi sains yang ditindaklanjuti pada kegiatan modifikasi bentuk perkuliahan, sehingga kelak diharapkan mampu mengoptimalkan literasi sains mahasiswa.

\section{DAFTAR PUSTAKA}

Bagasta, A. (2018). Profil Kemampuan Literasi Sains Peserta Didik di Salah Satu SMA Negeri Kota Sragen. Pedagogia: Jurnal Pendidikan, 7(2), 121-129

Budiarti, I. S. (2021). Analysis on students' scientific literacy of Newton's law and motion system in living things. Jurnal Pendidikan Sains Indonesia (Indonesian Journal of Science Education), 9(1), 36-51. https://doi.org/10.24815/jpsi.v9i1.18470

Fadlika, R. H., Mulyani, R., \& Dewi, T. N. S. (2020). Profil Kemampuan Literasi Sains Berdasarkan Gender di Kelas X. Quagga: Jurnal Pendidikan Dan Biologi, $12(2), 104$. https://doi.org/10.25134/quagga.v12i2.2326

Hendri, S., \& Hasriani. (2019). Identifikasi Literasi Sains Mahasiswa (Studi Kasus Mahasiswa STISIP Amal IImiah Yapis Wamena). Journal of Natural Science and Integration, 2(1), 95. https://doi.org/10.24014/jnsi.v2i1.7117 
Hidayah, N., Rusilowati, A., \& Masturi, M. (2019). ANALISIS PROFIL KEMAMPUAN LITERASI SAINS SISWA SMP/MTs DI KABUPATEN PATI. Phenomenon: Jurnal Pendidikan MIPA, 9(1), 36-47. https://doi.org/10.21580/phen.2019.9.1.3601

Ilsadiati, Mislinawati, T. (2017). Analisis Kemampuan Literasi Sains Siswa Kelas V pada Pembelajaran IPA di SD Negeri Unggul Lampeuneuryt Aceh Besar. Jurnal IImiah Pendidikan Guru Sekolah Dasar, 2(4), 27-35

Limiansih, K. (2021). PEMBELAJARAN SAINS TINGKAT SD DI PAPUA: REFLEKSI MAHASISWA PGSD. SNFKIP 2021: Pendidikan Bagi Masyarakat Di Daerah 3T, $66-80$

Listiani, I. (2016). Efektivitas Model Pembelajaran Science Technology Society (Sts) Disertai Dengan Mind Map (Mm) Untuk Memberdayakan Keterampilan Proses Sains Siswa. Premiere Educandum : Jurnal Pendidikan Dasar Dan Pembelajaran, 5(01), 112-128. https://doi.org/10.25273/pe.v5i01.328

Rahmadani, Y., Fitakurahmah, N., Fungky, N., Prihatin, R., Majid, Q., \& Prayitno, B. A. (2018). Profil Keterampilan Literasi Sains Siswa di Salah Satu Sekolah Swasta di $\begin{array}{lllll}\text { Karanganyar. Jurnal Pendidikan } & 183 .\end{array}$ https://doi.org/10.24114/jpb.v7i3.10123

Schleicher, A. (2019). PISA 2018 Insights and Interpretations. In OECD.

Sugiyono. (2014). Metode penelitian kuantitatif, kualitatif, dan R\&D. Bandung: Alfabeta

Widiyati, D., Sumantri, M. S., \& Lestari, I. (2020). Profil Kemampuan Literasi Sains Peserta Didik Sekolah Dasar (Studi Kasus Di Sekolah Dasar Swasta Adik Irma Kecamatan Tebet). Prosiding Seminar Dan ..., 1-7. http://journal.unj.ac.id/unj/index.php/psdpd/article/view/17757

Widya, R., \& Sanjaya, K. (2017). Pengembangan Modul Berbasis Bounded Inquiry Lab Untuk. Jurnal Inkuiri, 6(3), 1-16

Wiedarti, P., Laksono, K., Retnaningdyah, P., Dewayani, S., Muldian, W., \& Dkk. (2016). DESAIN INDUK GERAKAN LITERASI SEKOLAH. In Analisis Standar Pelayanan Minimal Pada Instalasi Rawat Jalan di RSUD Kota Semarang (Vol. 1)

Winata, A. (2018). KEMAMPUAN AWAL LITERASI SAINS PESERTA DIDIK KELAS V. Jtiee, 2(1), 58-64

Windyariani, S. (2018). KEMAMPUAN LITERASI SAINS SISWA SD PADA KONTEKS MELESTARIKAN CAPUNG. BIOSFER JURNAL PENDIDIKAN BIOLOGI, 10(1), 17-21. https://doi.org/10.21009/biosferjpb.10-1.3

Wulandari, N., \& Wulandari, N. (2016). Analisis Kemampuan Literasi Sains Pada Aspek Pengetahuan Dan Kompetensi Sains Siswa Smp Pada Materi Kalor. Edusains, 8(1), 66-73. https://doi.org/10.15408/es.v8i1.1762 